\title{
The Untapped Wealth of Manuscripts on Indian Astronomy and Mathematics
}

\author{
M. D. Srinivas* \\ Centre for Policy Studies, Chennai-600069
}

(Received 31 March 2019; revised 06 June 2019)

\begin{abstract}
Unlike in the case of other classical sciences of India, the vast corpus of manuscripts in Indian astronomy and mathematics has been extensively surveyed and documented during the last fifty years, mainly due to the painstaking efforts of D. Pingree and K. V. Sarma. We shall make use of their documentation to make: (i) an estimate the extent of available source-works in Indian astronomy and mathematics; and (ii) an assessment of what has been accomplished by the modern scholarship of last two centuries by way of editing and translating these source-works. We find that of the estimated 9,000 source-works of Indian Astronomy and Mathematics (which are preserved in around 30,000 manuscripts), only about 150 texts were edited, and just 30 texts translated during 1800-1947. During 1948-2019, there has been significant progress and another about 300 texts have been edited and 66 texts translated, many of them with detailed explanatory notes. Thus, only about 450 (or $5 \%$ of the estimated 9000 source-texts available) have been edited and published so far; even among the published works, only 96 texts have been seriously studied via translations and explanations with a view to bring out their technical (mathematical-astronomical) content. There is an urgent need to reorient our national priorities and give due importance to the preservation, digitization, listing and cataloguing, editing \& publishing, and promoting systematic studies of the large corpus of source-works of the great tradition of science and technology in India. Training young scholars for undertaking all these tasks should indeed form an integral part of the courses and research conducted in our institutions of higher learning.
\end{abstract}

Key words: Census of exact sciences in Sanskrit, D. Pingree, K. V. Sarma, Manuscript wealth of India, National Manuscripts Mission, New catalogus catalogorum, Sanskrit manuscripts in science in Kerala and Tamil Nadu, Source-works in astronomy and mathematics, Union catalogue of Tamil manuscripts.

\section{Estimates of the manuscript wealth of India}

The first systematic survey of catalogues of Indian manuscripts in various repositories was published by Klaus Janert in 1965, where he estimated that the total

DOI: $10.16943 / \mathrm{ijhs} / 2019 / \mathrm{v} 54 \mathrm{i} 3 / 49738$

*Email: mdsrinivas50@gmail.com number of Indian manuscripts could be more than one million (Janert, 1965, p. 9):

We have reason to suppose that more than one million of Indian manuscripts are deposited in libraries, public or private and that more than 600,000 different manuscripts have been listed in some manner in printed catalogues since the origin of Indian studies a century and a half ago. 
Janert (1965, p. 9 fn) also noted that:

The present ... Annotated Bibliography of Catalogues of Indian Manuscripts contains 339 titles of publications comprising approximately $700 \mathrm{sep}$ arate volumes, parts or fascicles with a total of nearly 185,000 pages and about 550,000 catalogue entries of Indian manuscripts 500,000 of which were catalogued or listed in India.

As of date, the most comprehensive survey of the catalogues of Indian manuscripts is the one published by Subhash Biswas and M. K. Prajapati in 1998, and they estimated the total number of Indian manuscripts to be around 3.5 million, of which only about a million had been catalogued (Biswas and Prajapati, 1998, p. xiv):

There are some 3.5 million manuscripts in various collections in India. In addition about 60,000 Indian manuscripts are preserved in 20 different countries of Europe and North America. Several other countries in Asia also have nearly 150,000 manuscripts in Indian scripts and languages. ...

Only about one million manuscripts have been recorded in published catalogues or hand lists brought out by libraries and institutions. It was also found that several private and institutional collections remained unattended for years, without even being recorded or listed in any form. These one million manuscripts have been listed in about 2,000 volumes of catalogues published till about 1990; out of these nearly 300 were published by overseas institutions.

Biswas and Prajapati (1998, p. xx) also presented the language-wise distribution of the catalogued manuscripts, which is given in Table 1.

In September 1998, while announcing the proposal to establish a National Mission for Manuscripts, it was mentioned that there were around 30 million Indian manuscripts: ${ }^{1}$

A national mission is being set up for the preservation of hundreds and lakhs of manuscripts scattered all over the country. ... The mission is to be

${ }^{1}$ http://pibarchive.nic.in/archive/releases98/ lyr98/10998/r070998.html (accessed on 15 March 2019).
Table 1 Language-wise distribution of the catalogued Indian manuscripts

\begin{tabular}{|l|r|r|}
\hline \multicolumn{1}{|c|}{ Language } & \multicolumn{1}{c|}{$\begin{array}{c}\text { No. of } \\
\text { Manuscripts }\end{array}$} & Percentage \\
\hline $\begin{array}{l}\text { Sanskrit, Prākṛt, } \\
\text { Apabhramsśa }\end{array}$ & $8,29,653$ & 78.39 \\
\hline $\begin{array}{l}\text { Hindi (Bhāșā, } \\
\text { Maithili, Bhojpuri, } \\
\text { Rajasthani, etc.) }\end{array}$ & 87,412 & 8.26 \\
\hline Tamil & & \\
\hline Gujarati & 39,666 & 3.75 \\
\hline Persian & 16,121 & 1.52 \\
\hline Kannada & 14,722 & 1.39 \\
\hline Malayalam & 13,818 & 1.31 \\
\hline Urdu & 11,815 & 1.12 \\
\hline Telugu & 10,029 & 0.95 \\
\hline Marathi & 9,216 & 0.87 \\
\hline Bengali & 6,552 & 0.62 \\
\hline Panjabi & 4,915 & 0.46 \\
\hline Arabic & 4,107 & 0.39 \\
\hline Pali & 2,949 & 0.28 \\
\hline Oriya & 2,050 & 0.19 \\
\hline Tibetan & 1,826 & 0.17 \\
\hline Sinhalese & 1,364 & 0.13 \\
\hline Assamese & 1,317 & 0.12 \\
\hline Others & 778 & 0.07 \\
\hline Total & 114 & 0.01 \\
\hline
\end{tabular}

launched in three phases. The first phase will comprise compilation and publication of a directory of institutions/individuals possessing these manuscripts and collecting data on their historical importance and physical state and preservation facilities available. The second phase envisages analysis of the data collected in the first phase and physical verification and preparation of a national register of these manuscripts, which have national and international importance. The third stage will be digitalisation of these rare manuscripts in order to increase accessibility without physical handling.

More than 30 million manuscripts remain scattered all over the country. The Minister for $\mathrm{Hu}$ man Resource Development, Murli Manohar Joshi while chairing a meeting of the Advisory Board 
of National Library recently, expressed concern over this and said that to protect these, which are our cultural heritage, a national mission for their preservation must be set up.

In a review article on 'Indian Manuscripts' (written in 2011 and published in 2014) Dominik Wujastyk also concurred with this estimate of 30 million manuscriptswhich, he notes, was also the estimate made by David Pingree (Wujastyk, 2014, pp. 169-160): ${ }^{2}$

How many Indian manuscripts are there? The National Mission for Manuscripts in New Delhi works with a conservative figure of seven million manuscripts, and its database is approaching two million records (http://www namami . org/manuscriptdatabase.htm, consulted 18 August 2011). The late Prof. David Pingree, basing his count on a lifetime of academic engagement with Indian manuscripts, estimated that there were thirty million manuscripts, if one counted both those in public and government libraries, and those in private collections (David Pingree, personal communication in the 1990s). For anyone coming to Indian studies from another field, these gargantuan figures are scarcely credible. But after some acquaintance with the subject, and visits to manuscript libraries in India, it becomes clear that these very large figures are wholly justified. The Jaina manuscript library at Koba in Gujarat, which only started publishing its catalogues in 2003, has an estimated 250,000 manuscripts. The Sarasvati Bhavan Library in Benares has in excess of 100,000 manuscripts. There are 85,000 in various repositories in Delhi. There are about 50,000 manuscripts in the Sarasvati Mahal library in Thanjavur in the far South. Such examples are easily multiplied across the whole subcontinent. And these are only the public libraries with published catalogues. A one-year pilot field-survey by the National Mission for Manuscripts in Delhi, during 2004-2005, documented 650,000 manuscripts distributed across 35,000 repositories in the states of Orissa, Bihar

\footnotetext{
${ }^{2}$ The figure of 30 million Indian manuscripts is also mentioned by Sheldon Pollock who contrasts it with the total of about 30,000 Greek manuscripts (covering the classical, Hellenistic and Byzantine periods) which are extant ( Pollock, 2006, p. $558 \&$ fn).
}

and Uttar Pradesh, and field participants in that project report that they only scratched the surface.

The National Manuscripts Mission gives a more modest estimate of 10 million Indian manuscripts on its current webpage: ${ }^{3}$

The National Mission for Manuscripts was established in February 2003, by the Ministry of Tourism and Culture, Government of India. A unique project in its programme and mandate, the Mission seeks to unearth and preserve the vast manuscript wealth of India. India possesses an estimate of ten million manuscripts, probably the largest collection in the world.

The Mission also gives the summary of its performance so far, which mentions that over 4.2 million manuscripts have been documented: 4

i 42.03 lakhs manuscripts have been documented.

ii Set up a web-based National database of manuscripts with information on 2.7 million manuscripts.

iii 1st, 2nd and 3rd phase of the digitization of manuscripts project is completed and 4th phase is in process. Total 2.96 lakhs manuscripts (2.61 Crore Pages) have been digitized.

iv Initiated a Publication programme. 30 unpublished manuscripts have been published.

Given the results of the surveys done by the NMM so far, it does seem that 10 million is indeed a reasonable estimate for the number of Indian manuscripts that are extant; of these, perhaps only about 2 to 3 lakhs are in repositories outside India. Again, the number of manuscripts in Sanskrit can be expected to be of the order of 8 million.

\footnotetext{
${ }^{3}$ https: //www. namami.gov. in/national-missionmanuscripts (accessed on 15 March 2019).

${ }^{4}$ https://www.namami.gov.in/performance-summary (accessed on 15 March 2019).
} 


\section{The distribution of manuscripts over different disciplines}

\subsection{Catalogus Catalogorum and the New Catalogus Catalogorum}

Many of the descriptive catalogues published by different manuscript repositories list the manuscripts in different disciplines separately; some of them may mention the discipline along with the title of each text, while listing its manuscripts. To make any assessment of the extent of manuscripts in different disciplines, what is required is to systematically compile the information provided in various catalogues into some sort of a 'union catalogue' which lists all the works along with various details such as the author, discipline, etc., provided in the individual catalogues.

The first such compilation was made by Theodor Aufrecht in his Catalogus Catalogorum, which was published in three volumes during 1891-1903 (Aufrecht, 1891, 1896 and 1903). Aufrecht's work was based on 94 catalogues and his first volume listed about 60,000 works and authors alphabetically, with appropriate catalogue references.

In 1935, the University of Madras initiated a programme of updating the Aufrecht's work, as many more catalogues had become available by then. A provisional fasciculus of the New Catalogus Catalogorum (NCC) was issued under the editorship of S. Kuppuswami Sastri in 1937. The first volume (covering the letter ' $a$ ') appeared in 1949 under the editorship of C. Kunhan Raja with the assistance of V. Raghavan. In the 1950s the work got intensified and two Research Assistants (K. V. Sarma and C. S. Sundaram) were appointed to assist Raghavan. During 1966-69, a revised edition of volume I was published along with volumes II-IV (covering ' $a$ ' to ' $g \bar{a}$ ') under the editorship of V. Raghavan. Volumes VI-XI (covering ' $g \bar{a}$ ' to ' $p a$ ') were published during 1971-83 under the editorship of K. Kunjunni Raja. Volumes XII-XIV (covering ' $p a$ ' to ' $b r a$ ') were published during 1988-2001 under the editorship of $\mathrm{N}$. Veezhinathan. And, volumes XVXXXIX (covering ' $b r a$ ' to 'su') have been published during 2007-15 under the editorship of Siniruddha Dash. The remaining couple of volumes are expected to be published shortly.

The volumes I-XIV present manuscript references and other details based on around 400 catalogues and a large number of secondary sources. Volumes XV-XXXIX have compiled details from over 900 catalogues along with the secondary sources. It may be estimated that, when completed, the entire series of volumes of NCC will have information on over 300,000 works and authors. The works have been classified under various subject heads which is reproduced in Table 2 .

An estimate of the extent of manuscript wealth in any discipline can be had by compiling the entries in various volumes of NCC that come under each subject category/categories. Such an analysis is yet to be undertaken.

\subsection{Union Catalogue of Tamil Manuscripts}

As regards the wealth of manuscripts in different disciplines, there is detailed information available only for the case of Tamil Manuscripts. In 1991, the Tamil University Thanjavur, published a five volume Union Catalogue of 21,973 Tamil Manuscripts listed in various published catalogues from 17 Indian repositories (holding 20,804 manuscripts) and 22 repositories abroad (holding 1,169 manuscripts). The last of these volumes gives a bibliometric analysis of about 21,875 manuscripts whose subjects could be identified among a list of about 330 subject-headings. The subject-wise distribution of Tamil manuscripts given in Table 3, has been worked out on the basis of this bibliometric analysis (Sellamutthu et al, 1991, pp. 2148-2156).

From Table 3, we can see that religion, philosophy and other humanities and social sciences, account for about $41.5 \%$ of the Tamil manuscripts; literature accounts for another $30 \%$ of the manuscripts. The rest, which constitute about $28.5 \%$ of the manuscripts are in various sciencesincluding the science of language which accounts for nearly $6 \%$ of the manuscripts. About 3,350 manuscripts (constituting $15.3 \%$ of the total) deal with medicine and about 1,250 manuscripts (5.7\% of the total) are said to deal with astrology. It is reported that there are about 120 manuscripts each on astronomy and mathematics and chemistry, 100 on architecture and 40 on chemistry.

\subsection{Survey of Sanskrit Manuscripts on Science in Kerala and Tamil Nadu by K. V. Sarma}

During 1995-97, K. V. Sarma did a painstaking survey of 247 manuscript repositories in Kerala and 147 manuscript 
Table 2 Subject-heads used in New Catalogus Catalogorum

\begin{tabular}{|c|c|}
\hline \multicolumn{2}{|c|}{ Subjects } \\
\hline adv. - advaita. & med. - medicine. \\
\hline alaṃk. - alaṃkāra. & mim. - Mīmāṃsā (pūrva). \\
\hline anu. adv. - anubhavādvaita. & ny. - nyāya. \\
\hline Āpāst. - Āpastamba. & paur. - paurāṇika. \\
\hline Āśval. - Āśvalāyana. & pr. - prayoga. \\
\hline Av, Ath. v. - Atharvaveda. & rel. - religion. \\
\hline Bhārad. - Bhāradvāja. & Rv. - Ṛgveda. \\
\hline Bodh., Baudh. - Bodhāyana, Baudhāyana. & śai. - śaivism. \\
\hline Br.-Brāhmạ̣as & Śāṅkh. - Śāṅkhāyana. \\
\hline Bud. - Buddhistic. & śr. - Śrauta. \\
\hline dh. - dharmaśāstra. & śrivaiṣ - śrivaiṣṇava. \\
\hline Dig. - Digambara. & sū. - sūtra. \\
\hline Drāhyā. - Drāhyāyaṇiya. & Sv. - Sāmaveda. \\
\hline dvai. - dvaita. & Śvet. - śvetāmbara. \\
\hline gr. - grammar. & Taitt. - Taittirīya. \\
\hline gṛh. - gṛhya. & Up(s). - Upanișad(s). \\
\hline Hiraṇ., Hiraṇyak. - Hiraṇyakeśiya. & vaid. - vaidic. \\
\hline jy. - jyotișa. & Vaikh. - Vaikhānasa. \\
\hline Kāś. Sai. - Kāśmir Śaivism. & vaiś. - vaiśeșika \\
\hline Kāty. - Kātyāyana. & vaiṣ. - vaiṣṇava. \\
\hline Kṛ. Yv., Kṛṣṇ. Yv. - Kṛṣna Yajurveda. & Vāj., Vs. - Vājasaneya, Vājasaneya saṃhitā \\
\hline lex. - lexicon & ved. - vedic. \\
\hline mā. - māhātmya. & viś.,(v).adv. - viśișțādvaita. \\
\hline Mādh. - Mādhyandina. & Yv. - Yajurveda. \\
\hline
\end{tabular}


Table 3 Subject-wise distribution of Tamil manuscripts

\begin{tabular}{|l|r|r|}
\hline \multicolumn{1}{|c|}{ Subject } & \multicolumn{1}{|c|}{$\begin{array}{c}\text { No. of } \\
\text { Manuscripts }\end{array}$} & Percentage \\
\hline Medicine & 3,350 & 15.31 \\
\hline Astrology & 1,250 & 5.71 \\
\hline $\begin{array}{l}\text { Astronomy and } \\
\text { Mathematics }\end{array}$ & 120 & 0.55 \\
\hline Chemistry & 120 & 0.55 \\
\hline Architecture & 60 & 0.27 \\
\hline $\begin{array}{l}\text { Veterinary } \\
\text { Science }\end{array}$ & 40 & 0.18 \\
\hline $\begin{array}{l}\text { Grammar, } \\
\text { Prosody, Lexicon }\end{array}$ & 1,300 & 5.94 \\
\hline $\begin{array}{l}\text { Music and } \\
\text { Dance }\end{array}$ & 220 & 1.00 \\
\hline Drama & 210 & 0.96 \\
\hline Literature & 6,100 & 27.89 \\
\hline $\begin{array}{l}\text { Religion } \\
\text { (Samayam) }\end{array}$ & 6,700 & 30.63 \\
\hline Philosophy & 1,725 & 7.89 \\
\hline $\begin{array}{l}\text { Dharmaśāstra } \\
\text { (Nìtinūl) }\end{array}$ & 400 & 1.83 \\
\hline $\begin{array}{l}\text { Other } \\
\text { Humanities and } \\
\text { Social Sciences }\end{array}$ & 280 & 1.28 \\
\hline Total & $\mathbf{2 1 , 8 7 5}$ & $\mathbf{1 0 0}$ \\
\hline
\end{tabular}

repositories in Tamil Nadu. During the course of this survey, about 150,000 manuscripts 'were examined partly in situ in person and partly through their catalogues or hand-lists when available' (Sarma, 2002, p. 15). The Survey revealed that of the total of 150,000 manuscripts surveyed, 12,244 manuscripts (more than $8 \%$ ) pertained to various sciences including astrology (jātakaskandha and saṃhitāskandha of jyotișa), astronomy and mathematics (ganitaskandha of jyotisa, which includes mathematics also), medicine (āyurveda), architecture (śilpaśāstra), musicology (sañgītaśāstra), chemistry (rasaśāstra), veterinary science (mrgaśāstra) and agriculture (krșiśāstra).

The manuscripts on astrology, astronomy and mathematics and medicine together accounted for 11,000 (or $90 \%$ ) of the manuscripts pertaining to science. However, unlike in the case of the Tamil manuscripts, the Sanskrit manuscripts on astronomy and mathematics constituted a much larger proportion (nearly $25 \%$ of the manuscripts on science, and $30 \%$ of the manuscripts in jyotisa) while the Sanskrit manuscripts on medicine were only $10 \%$ of the total Sanskrit manuscripts on science. Sarma's survey also found that these 12,244 manuscripts actually correspond to about 3,473 separate texts, of which only 229 or about $6.6 \%$ of these texts had been edited and published so far. In Table 4, we have summarised the discipline-wise distribution of manuscripts and texts as found in the survey (Sarma, 2002, p. 15):

\section{Manuscripts and source-works in Astronomy and Mathematics}

Among the ancient Indian sciences, astronomy and mathematics occupy a prime position along with the sciences of language and health. All these sciences are distinguished by an extensive textual tradition which goes back to the Vedic period and the tradition continued to flourish till at least the middle of the nineteenth century. As we saw above, a significant part of the great manuscript wealth of India pertains to these sciences, which have played an important role in the history of our civilisation.

Unlike in the case of other ancient Indian sciences, the vast corpus of manuscripts in astronomy and mathematics has been extensively surveyed and documented by modern scholarship during the last fifty years. One of the earliest surveys of the manuscripts in astronomy and mathematics was conducted in early 1960s at the behest of the National Institute of Sciences of India (later named the Indian National Science Academy) by Samarendra Nath Sen with the assistance of Amulya Kumar Bag and Sreeramula Rajeswara Sarma (1966). Their Bibliography was based on information compiled from 79 catalogues and listed 660 works under 480 authors, together with another 320 works whose authors were not known. For each title, catalogue references were provided to the manuscripts, along with other details, wherever available. Since the information compiled was based only on 79 catalogues, this Bibliography should be considered as a preliminary survey of the vast corpus of manuscripts in the field of astronomy and mathematics.

A comprehensive survey of the manuscripts and sourceworks on Indian astronomy and mathematics was undertaken by David Pingree. Pingree, it seems, embarked on this mammoth enterprise in 1955, and he was still work- 
Table 4 Subject-wise distribution of Sanskrit manuscripts on science in Kerala and Tamil Nadu

\begin{tabular}{|l|r|r|r|r|}
\hline \multicolumn{1}{|c|}{ Subject } & $\begin{array}{c}\text { No. of } \\
\text { Manuscripts }\end{array}$ & Percentage & No. of Texts & \multicolumn{1}{c|}{$\begin{array}{c}\text { No. of Texts } \\
\text { Edited so far }\end{array}$} \\
\hline Astrology & 6,794 & 4.53 & 1,572 & 65 \\
\hline $\begin{array}{l}\text { Astronomy } \\
\text { and } \\
\text { Mathematics }\end{array}$ & 2,919 & 1.95 & 934 & 100 \\
\hline Medicine & 1,286 & 0.86 & 586 & 28 \\
\hline Architecture & 599 & 0.40 & 200 & 10 \\
\hline Musicology & 326 & 0.22 & 82 & 9 \\
\hline Chemistry & 166 & 0.11 & 61 & 4 \\
\hline $\begin{array}{l}\text { Veterinary } \\
\text { Science }\end{array}$ & 146 & 0.10 & 31 & 0 \\
\hline Agriculture & 8 & & & $\mathbf{2 2 9}$ \\
\hline Total & $\mathbf{1 2 , 2 4 4}$ & $\mathbf{8 . 1 6}$ & $\mathbf{3 , 4 7 3}$ & \\
\hline $\begin{array}{l}\text { Total } \\
\text { Manuscripts } \\
\text { Surveyed }\end{array}$ & $\mathbf{1 5 0 , 0 0 0}$ & & & \\
\hline
\end{tabular}

ing on it at the time of his demise in 2005. Five volumes of Pingree's Census of Exact Sciences in Sanskrit (covering all authors from ' $a$ ' to ' $v a$ ', in about 1,700 pages) appeared during 1970-1994 (1970, 1971, 1976, 1981 and 1994). ${ }^{5}$ The scope of the Census is outlined in the introduction to the first volume (Pingree, 1970, p. viii):

... Census of the Exact Sciences in Sanskrit (hereafter to be referred to as CESS)...will provide all available bibliographical information concerning works in jyotihśástra and related fields and biographical information concerning their authors. Jyotihśāastra is divided into three skandhas or branches: hora or genethlialogy and other forms of horoscopic astrology, ganita or mathematics and mathematical astronomy, and saṃhitā or divination. The related fields to which attention is paid in CESS are cosmology and geography (largely of the Jainas) and those aspects of dharmaśāstra that involve the determination of the proper times for the performance of ritual acts. It is intended to include all the works and all the authors in these subjects that can be identified.

\footnotetext{
${ }^{5}$ The last volume in the Series A was said to be nearly complete when Pingree passed away in 2005; unfortunately, it still remains unpublished.
}

CESS will consist of two series: Series A will contain articles on authors arranged in the order of Sanskrit alphabet, and the Series B articles on the Books (mainly in Sanskrit, though some nonSanskritic material is included arranged in the same manner ...The article on each author will first give as much information as is available on his date, ancestry, locale, religious affiliation, and social position; it will then list his works relevant to jyotihśāastra, and, under each work, list its commentators, its manuscripts and editions, and any discussions of it; finally there will be given a table of its contents and those passages in it which inform us about the author.

In the preface to the same volume, Pingree (vol. I, 1970, p. vii) mentions that:

... the individual to whom this cataloguer owes most is India's foremost student of Sanskrit manuscripts, Professor V. Raghavan of the University of Madras, who most generously made available his numerous handwritten catalogues of Indian and European collections. May this work prove as useful to the students of jyotiḩśāstra as Raghavan's New Catalogous Catalogorum is to the students of Sanskrit literature in general. 
Around 400 catalogues are listed in the first volume of the Census. Supplementary lists are given in each successive volume so that the total number of catalogues from which the information has been compiled adds up to around 600. The volumes of the Census also present a comprehensive bibliography of secondary sourceslisting over 2,000 articles and books related to jyotiḩśāstra.

The first four volumes of the Census (covering letters ' $a$ ' to ' $m a$ ') included information on 2,450 authors in all. The corresponding information in the case of volume $\mathrm{V}$ (covering letters ' $y a$ ' to ' $v a$ ') was not provided. It is estimated that, when the contents of the unpublished sixth volume is also taken into account, the total number of authors could be more than 4,000.

The volumes of the Census constitute a rich source for studying all aspects of the large corpus of manuscripts in jyotihśāstra such as: The total number of manuscripts, the total number of source-works and their distribution over different sub-disciplines and the historical periods and locations of the authors, details of source-works which have been edited, translated and studied, and so on. Such studies have not been carried out so far-perhaps because, like in the case of NCC, the volumes of the Census are not yet complete.

In his survey of the literature on jyotihśāstra, published in 1981, Pingree himself estimated the total number of Sanskrit manuscripts pertaining to jyotihsśāstra to be around 100,000 (Pingree, 1981, p. 118):

At present there exist in India and outside of it some 100,000 manuscripts on the various aspects of jyotihśāstra. The great majority of these were copied within the seventeenth, eighteenth, and nineteenth centuries; for manuscripts cannot long survive in India except under exceptional circumstances.

We may now recall the findings of the Survey of Sanskrit manuscripts in Kerala and Tamil Nadu, due to K. V. Sarma (mentioned earlier), which found 6,714 manuscripts (corresponding to 1572 works) on astrology and 2,919 manuscripts (corresponding to 934 works) in astronomy and mathematics. Hence, we can conclude that out of the estimated 100,000 manuscripts on jyotihśāstra, the number of manuscripts pertaining to astronomy and mathematics could be around 30,000. Again, using the result of the same survey, we can also conclude that these 30,000 manuscripts are associated with roughly around 9,000 source-works on astronomy and mathematics in Sanskrit. This is indeed a huge wealth of literature, much of which (as we shall see below) remains untapped so far.

Apart from the Bibliography of Sen, and the five volumes of the Census and the monograph on the literature on jyotihśāstra due to Pingree (cited above), the other important sources which provide us valuable information regarding the source-works in Indian astronomy and mathematics (and details regarding their published editions, translations, etc.), are:

i Two monographs on Sanskrit Astronomical Tables in America and England by Pingree (1968, 1973)

ii The seminal bibliography of the works of Kerala School of Astronomers by K. V. Sarma (1972), and

iii The survey of K. V. Sarma on the Science Texts in the Manuscript Repositories of Kerala and Tamil Nadu (mentioned earlier).

Here, we shall essentially make use of the above sources to assess the progress achieved by modern scholarship of the last two and a half centuries in comprehending the Indian tradition of astronomy and mathematics by way of studying, editing, translating and analysing the technical contents of the large corpus of nearly 9,000 source-works as estimated above.

\section{Modern scholarship in Indian Astronomy and Mathematics: An assessment of its progress over the last two and a half centuries}

The Indian tradition of astronomy and mathematics was fairly flourishing during the eighteenth century and, in several parts of the country, the tradition continued well into the middle of the nineteenth century. However, the British policy of stopping all allocations for the support of indigenous learning (both by the local village societies as well as by the former Indian rulers), coupled with the policy of exclusively reserving all Governmental jobs to those who were trained in the new English education system, led to a steep decline in indigenous learning during the course of the nineteenth century. 
We shall here focus on the growth of modern scholarship-the modern phase of the European scholarship-in Indian astronomy and mathematics which may be said to have been initiated in the second half of the eighteenth century by the British and European scholars (and the British administrators in India). In the initial period, most of the investigations were confined to the analysis and interpretation of Indian astronomical tables which had been transmitted to Europe from India (and even Southeast Asia) during the course of the seventeenth and eighteenth centuries. More systematic studies of the source-works of Indian astronomy and mathematics began in the 1780s, some of which were published in the journal Asiatic Researches brought out by the Asiatic Society, established in Calcutta in 1784 .

\subsection{Source-works in Indian Astronomy and Mathematics edited/translated during 1800-1875}

To start with, we consider the source-works which were edited/translated during the period 1800-1875. The first full-fledged translations of Indian mathematics texts appeared during the decade, 1810-1820, starting with the translation of Bījagaṇita and Līlāvatī of Bhāskarācārya (ca.1150), by E. Strachey and J. Taylor in 1813 and 1816 respectively. This was soon followed in 1817 by a more authoritative translation, along with detailed explanation of the mathematical content of these works (based on an examination of their traditional commentaries), by Henry Thomas Colebrooke (1817). Colebrooke's work also included a translation of the Ganita and Kuttaka chapters of the Brāhmasphutasiddhānta of Brahmagupta (ca.628). In the meanwhile, there also appeared a brief translation, due to Benjamin Hyne, of the Geometry section of the Telugu work, Pāvalürigaṇitamu (which is said to be a translation of Gaṇitasārasañgraha of Mahāvīra (ca.850)), by Mallana (ca.1100). However, for the next several decades, there seems to have been little progress in the translation of source-texts of Indian Mathematics, till George Thibaut took up the study of the Śulvasūtras in the 1870s.

Editions of Indian source-works started appearing in the 1830s. Here again, the Sanskrit texts of Lìlāvatī and Bījagaṇita of Bhāskarācārya were the first to be published from Calcutta in 1832 and 1834. The British administrator Lancelot Wilkinson had gathered a group of traditional In- dian scholars at Sehore and he published an edition of the celebrated treatise, Siddhāntaśiromaṇi of Bhāskarācārya, along with the auto-commentary Vāsanābhāṣya, from Calcutta in 1842. In the next year, Wilkinson published an edition of the famous astronomical manual (karana) Grahalāghava of Gaṇeśa Daivajña (ca.1520) along with the commentary of Mallāri (ca.1588). In 1859, Fritz Edward Hall and Bāpū Deva Śāstri (the doyen among traditional scholars, who had also been trained in modern learning in the Sanskrit College of Varanasi) published an edition of the Sūryasiddhānta along with the commentary Gū as a part of the Bibliotheca Indica series from Calcutta. Another major publication in this series was the edition by H. Kern of the famous Brhatsam hitā of Varāhamihira (ca.550). But the crowning achievement of this period was the publication from Leiden of an edition of the seminal text of Indian astronomy-the Āryabhațiya of Āryabhața (ca.499), along with the commentary Bhatadipikā of the Kerala Astronomer Parameśvara (ca.1430), by H. Kern in 1874.

As regards translations of source-works of Indian Astronomy, a Marathi translation of the Siddhāntaśiromaṇi was published in 1837. In 1848, H. R. Hoisington of the Batticotta Seminary in Sri Lanka published an edition and translation (along with explanatory notes) of the popular work of the Vākya system, Cū dāmaṇi Ullamudaiyān (in Tamil) of Tirukkoțtiyūr Nambi (ca.1234). However, unlike the work of Colebrooke on Indian Mathematics which was published in 1817, the first detailed exposition in English of a classical Siddhāntic text of Indian Astronomy appeared only in 1860. This was the famous translation of Süryasiddhānta (together with detailed explanatory notes) by Rev. Ebenezer Burgess, which was revised by William Dwight Whitney (Burgess, 1860). ${ }^{6}$ Soon, this was followed by an English translation of the Golādhyāya of Siddhāntaśiromaṇi by Lancelot Wilkinson revised by Bāpū Deva Śāstri in 1861. Another landmark publication was the edition (and translation into German) of the $R k$ and the Yajus recensions of the ancient Vedā $\dot{n}$ gajyotisa (ca.1300-1100 BCE ), with the commentary of Somākara (ca.1350 CE) on the Yajus version, by Albrecht Weber from Berlin in 1862. The other two works which were translated during this period were the Brhatsam

\footnotetext{
${ }^{6}$ This work was first published in 1858 by the Journal of American
} Oriental Society 
Table 5 Source-works of Indian Astronomy and Mathematics edited/translated during 1800-2019.

\begin{tabular}{|c|c|c|}
\hline Period & No. of Source-works edited & No. of Source-works translated \\
\hline $1800-1875$ & 15 & 10 \\
\hline $1876-1947$ & About 135 & 20 \\
\hline $1948-2019$ & About 300 & 66 \\
\hline Total & About 450 & $\mathbf{9 6}$ \\
\hline
\end{tabular}

of Varāhamihira, which was translated by H. Kern during 1870-75, and the Grahalāghava of Ganeśa Daivajña (ca.1520) which was published along with the Udāharaṇa of Viśvanātha (ca.1600) and a Marathi Translation by K. S. Godbole and V. K. J. Gadre from Bombay in the 1870s.

\subsection{Source-works in Indian Astronomy and Mathematics edited/translated during 1876-2019}

We have referred to all the editions and translations that were published during 1800-1875, mainly because they were pioneering efforts, and also because there were indeed so few of them-only about 15 source-works were edited and about 10 translated (two of them only partially) in the entire seventy-five period under consideration. The next seventy-odd years, 1876-1947, indeed saw a substantial increase in the number of source-works edited. This was a period when a number of Indian scholars, most of them from a background of traditional scholarship, but trained also in modern institutions of higher learning (including the new institutions of Sanskritic learning), started playing a leading role in the editing and translating source-works of Indian Astronomy and Mathematics.

The prime mover in the editing of source-works was Sudhākara Dvivedin, a student of Bāpūdeva Sāstri in Varanasi, whose example was soon followed by number of scholars in Calcutta, Poona, Trivandrum and other places. During 1878-1910, Sudhākara Dvivedin edited and published more than twenty important texts, often with his own Sanskrit commentary. He also wrote a tract in Sanskrit, Ganakatarangiṇi, on the lives of Indian astronomers and mathematicians (Dvivedin, 1892). A really comprehensive history of Indian Astronomy was written in Marathi in 1895 by Sankara Balakrishna Dikshit, who took great pains to look through a large number of manuscripts and books to compile details of the works written by hundreds of Astronomers and Mathematicians from the ancient period to the modern times (Dikshit, 1896). Incidentally, Dikshit mentions in his preface that the Aufrecht's Catalogus Catalogorum contains titles of 2,000 works of Indian astronomy.

We have looked in detail through the comprehensive bibliographies of Sen, Pingree and Sarma, cited in the last section, to make a preliminary master list of the published translations of the source-works of Indian astronomy and mathematics during the last two centuries. We have presented the detailed list in Appendix A. What this list reveals is that while there were only 10 works which were translated during 1800-1875, this number rose to 20 during 1876-1947, and further increased substantially to 66 during 1948-2019. We have not made any detailed survey of the source-works which have been edited during 18761947 and 1948-2019. However, from our perusal of these bibliographies and other sources, it seems that the number texts edited during these periods may be estimated to be around 135 and 300 respectively. These summary figures are given in Table 5, and the list of the titles translated is given in Sections 4.2.1-4.2.4.

\subsubsection{List of source-works translated during 1800-1875}

1. Vedāngajyotișa of Lagadha (ca.1300-1100 BCE)

2. Bṛhatsaṃhitā of Varāhamihira (ca.550 CE)

3. Brāhmasphuțasiddhānta of Brahmagupta (ca.628) (PART)

4. Sūryasiddhānta

5. Pāvalūrigaṇitamu (in Telugu) of Mallaṇa (ca.1100) (PART)

6. Lìlāvatī of Bhāskarācārya (ca.1150)

7. Bījagaṇita of Bhāskarācārya (ca.1150)

8. Siddhāntaśiromaṇi of Bhāskarācārya (ca.1150) 
9. Cūḍāmaṇi Ulḷamudaiyān (in Tamil) of Tirukkoț̣iyūr Nambi (ca.1234)

10. Grahalāghava of Gaṇeśa Daivajña (ca.1520)

\subsubsection{List of source-works edited during 1800-1875}

1. Vedāngajyotișa of Lagadha (ca.1300-1100 BCE)

2. Āryabhațīya of Āryabhața (ca.499 CE)

3. Brhatsaṃhitā of Varāhamihira (ca.550)

4. Sūryasiddhānta

5. Līlāvatī of Bhāskarācārya (ca.1150)

6. Bījagaṇita of Bhāskarācārya (ca.1150)

7. Siddhāntaśiromaṇi of Bhāskarācārya (ca.1150)

8. Mitākșarā or Vāsanābhāṣya Autocommentary of Bhāskarācārya (ca.1150) on Siddhāntaśiromaṇi

9. Cūdāmaṇi Uḷlamuḍaiyān (in Tamil) of Tirukkoțtiyūr Nambi (ca.1234)

10. Commentary on Vedānigajyotișa by Somākara (ca.1350)

11. Bhațadīpikā on Āryabhațīya by Parameśvara (ca.1430)

12. Grahalāghava of Gaṇeśa Daivajña (ca.1520)

13. Commentary on Grahalāghava of Gaṇeśa Daivajña by Mallāri (ca.1588)

14. Udāharaṇa on Grahalāghava of Gaṇeśa Daivajña by Viśvanātha (ca.1600)

15. Gū $h$ ārthaprakāśaka on Sūryasiddhānta by Rañganātha (ca.1603)

\subsubsection{List of source-works translated during 1876-1947}

1. Baudhāyanaśulvasūtra (Prior to ca.800 BCE)

2. Āpastambaśulvasūtra (Prior to ca.800 BCE)

3. Kātyāyanaśulvasūtra (PART)

4. Mānavaśulvasūtra

5. Atharvañajyotișa

6. Sūryaprajñapti (in Prākṛta)

7. Candraprajñapti (in Prākṛta)

8. Āryabhațīya of Āryabhața (ca.499 CE)
9. Pañcasiddhāntikā of Varāhamihira (ca.550)

10. Khaṇdakhādyaka of Brahmagupta(ca.665)

11. Triśatikā of Śrīdhara (ca.750)

12. Dhavalā (in Prākṛta) of Vīrasena (ca.800) on Șatkhaṇ̣̂agama of Puṣpadanta and Bhūtabali

13. Gaṇitasārasañgraha of Mahāvīra (ca.850)

14. Laghumānasa of Muñjāla (ca.932)

15. Bhāsvatī of Śatānanda (ca.1099)

16. Makarandasāriṇ̄ of Makaranda (ca.1478)

17. Yantracintāmaṇi of Cakradhara (ca.15th Century)

18. Tithicintāmaṇi of Gaṇeśa Daivajña (ca.1530)

19. Sūryasiddhāntarahasya of Rāghavānanda Sarman (ca.1591)

20. Yantrarājaracanā of Savai Jayasimha (ca.1725)

\subsubsection{List of source-works of Indian Astronomy and Mathematics translated during 1947-2019}

1. Parāśaratantra of Parāśara (ca.1300-1100 BCE)

2. Kātyāyanaśulvasūtra

3. Bakṣāli Manuscript

4. Yavanajātaka of Sphūjidhvaja

5. Candravākya of Vararuci (ca. 4th Century CE)

6. Tiloyapaṇnatti (in Prākṛta) of Yatiṿ̣̦̂abha (ca. 5th Century)

7. Āryabhatasiddhānta of Āryabhața (ca.499) (PART)

8. Paitāmahasiddhānta of Viṣnudharmottarapurāṇa

9. Mahābhāskarīya of Bhāskara I (ca.620)

10. Brāhmasphuțasiddhānta of Brahmagupta (ca.628)

11. Āryabhațīyabhāṣya of Bhāskara I (ca.629)

12. Laghubhāskarīya of Bhāskara I (ca.635)

13. Karaṇaratna of Devācārya (ca.687)

14. Gaṇitapañcaviṃśī of Śrīdhara (ca.750)

15. Pātīgaṇita of Śrīdhara (ca.750)

16. Śș̣yadhīvrddhida of Lalla (ca.750)

17. Vāsanābhāṣya on Brāhmasphuțasiddhānta of Brahmagupta by Pṛthūdakasvāmin (ca.860) (PART)

18. Vațeśvara Siddhānta of Vateśvara (ca.904) 
19. Mahāsiddhānta of Āryabhața II (ca.950) (PART)

20. Karanatilaka of Vijayanandi (ca.966)

21. Trilokasāra (in Prākṛta) of Nemicandra (ca.975)

22. Dhīkoṭidakaraṇa of Śrīpati (ca.1039)

23. Siddhāntaśekhara of Śrīpati (ca.1039) (PART)

24. Ganitatilaka of Śrīpati (ca.1039)

25. Vāsanābhāṣya autocommentary of Bhāskarācārya on Bījagaṇita (ca.1150)

26. Mitākșarā or Vāsanābhāṣya autocommentary of Bhāskarācārya on Siddhāntaśiromaṇi (ca.1150) (PART)

27. Karaṇakutūhala (ca.1183) of Bhāskarācārya

28. Śulvadīpikā on Baudhāyanaśulvasūtra by Dvārakānātha Yajvan (ca.12th century)

29. Pañcavimiśatikā (ca. 13th Century)

30. Gaṇitasārakaumudī (in Prākṛta) of Țhakkura Pherū (ca.1320)

31. Gaṇitakaumudī of Nārāyaṇa Pạ̣ḍita (ca.1356)

32. Bījagaṇitāvataṃsa of Nārāyaṇa Paṇdita (ca.1356) (PART)

33. Yantrarāja of Mahendrasūri (ca.1370) (PART)

34. Yantrādhikāra of Padmanābha (ca.1400)

35. Dhruvabhramaṇādhikara of Padmanābha (ca.1400) (PART)

36. Sphuțacandrāpti of Mādhava (ca.1400)

37. Mahājyānayanaprakāra of Mādhava (ca.1400)

38. Lagnaprakaraṇa of Mādhava (ca.1400) (PART)

39. Grahaṇāșțaka of Parameśvara (ca.1410)

40. Grahanamaṇdana of Parameśvara (ca. 1410)

41. Grahaṇanyāyadīpikā of Parameśvara (ca.1432-33)

42. Goladīpikā II of Parameśvara (ca.1432-33)

43. Goladīpikā I of Parameśvara (ca. 1443-44)

44. Golasāra of Nīlakaṇtha Somayājī (ca.1500)

45. Tantrasangraha of Nīlakaṇțha Somayājī (ca.1500)

46. Candracchāyāgaṇita of Nīlakaṇṭha Somayājī (ca.1500)

47. Siddhāntadarpaṇa of Nīlakaṇtha Somayājī (ca.1500)
48. Autocommentary on Siddhāntadarpaṇa by Nīlakaṇtha Somayājī (ca.1500)

49. Grahasphutānayane Vikṣepavāsanā of Nīlakaṇtha Somayājī (ca.1500)

50. Kutțākāraśiromaṇi of Devarāja (ca.15th century)

51. Siddhāntasundara of Jñānarāja (ca.1503)

52. Pratodayantra of Gaṇeśa Daivajña (ca.1530)

53. Ekaviṃśatipraśnottara of Citrabhānu (ca.1530)

54. Gaṇitayuktibhāṣā (in Malayalam) of Jyeșțhdeva (ca.1530)

55. Sūryaprakāśa of Sūryadāsa on Bījagaṇita of Bhāskarācārya (ca. 1538)

56. Buddhivilāsinī on Lìlāvatī of Bhāskarācārya by Gaṇeśa Daivajña (ca.1545) (PART)

57. Turīyayantraprakāśa of Bhūdara (ca.1572)

58. Karaṇapaddhati of Putumana Somayājī (ca.1580)

59. Rāśigolasphuṭanīti of Acyuta Pișārați (ca.1585)

60. Candrārkī of Dinakara (ca.1589)

61. Bījapallava on Bījagaṇita of Bhāskarācārya by Kṛ̦̣na Daivajña (ca.1600) (PART)

62. Sarvasiddhāntarāja of Nityānanda (ca.1639) (PART)

63. Pāṭīsāra of Munīśvara (ca.1650) (PART)

64. Karaṇakesarī of Bhāskara (ca.1681)

65. Brahmatulyasāriṇ̄ of Malūkacandra (ca.17th Century)

66. Yantraprakāra of Savai Jayasisiṃha (ca.1725)

67. Sadratnamālā of Śañkaravarman (ca.1819)

68. Siddhāntadarpaṇa of Candraśekhara Sāmanta (ca.1869)

\subsection{Progress achieved during 1948-2019 in our understanding of Indian Astronomy and Mathematics}

As we saw, the period 1800-1875 saw several pioneering efforts to study the Indian tradition of astronomy and mathematics, but the overall number of source-texts which were edited or translated was indeed miniscule15 and 10, respectively, as noted in Table 5. An overview 
of what had been achieved by modern scholarship during the 19th century was presented by George Thibaut (1899) and Burgess (1893).

The next seventy-odd year period 1876-1947 did indeed see a significant increase both in the number of works edited and translated-135 and 20, respectively, as noted in Table 5. Many more details of the concepts, techniques and achievements of Indian mathematics had been unravelled by then and these were admirably summarised in the classic volumes on the History of Hindu Mathematics by Bibhutibhusan Datta and Avadhesh Narayan Singh in the 1930s. In this context, we may also cite the important work of Bibhutibhusan Datta on the Science of the Śulba: A Study in Early Hindu Geometry (1932). There is no similar overview of the state of our knowledge on Indian Astronomy in the 1930s-some idea can be had from the translation of Khaṇdakhādyaka of Brahmagupta by Prabodhchandra Sengupta (1934) and his introduction to the 1935 edition of the translation of Süryasiddhānta by Burgess (Sengupta, 1935, pp. vii-li).

Compared to the state of our knowledge of Indian Astronomy and Mathematics in the 1940s, it may be said that substantial progress has been achieved in the last seventy years, mainly by the dedicated efforts of a large number of scholars in studying, editing, translating and analysing the technical contents (mathematical and astronomical) of a number of important texts. As we noted in Table 5, during the period 1948-2019, it is estimated that nearly 300 source-works have been edited and 66 works have been translated-often with detailed explanatory notes. The impact of these editions/translations could already be seen in the review articles and books written on Indian Astronomy and Mathematics during the 1970s (or thereabout) (Iyengar, 1967; Bose, Sen and Subbarayappa, 1971; Pingree, 1978, Bag, 1979; Saraswati Amma, 1979; Sen and Shukla, 1985).

From the list of source-works translated during the period 1948-2019 as given in Appendix A, we can see that they include important works such as the Śulvasūtras, the Bakșāli Manuscript and many seminal works of the renowned Astronomers/Mathematicians: Lagadha, Parāśara, Sphūjidhvaja, Āryabhața, Varāhamihira, Bhāskara I, Brahmagupta, Devācarya, Śrīdhara, Lalla, Vațeśvara, Āryabhața II, Muñjāla, Śrīpati, Bhāskarācārya II, Ṭhakkura Pherū, Nārāyaṇa Paṇdita, Padmanābha, Mādhava, Parameśvara, Makaranda,
Nīlakaṇtha Somayājī, Devarāja, Jñānarāja, Gạ̣eśa Daivajña, Jyeșṭhadeva, Bhūdara, Putumana Somayājī, Acyuta Piṣārați, Sawai Jayasiṃha, Śan̉karavarman and Candraśekhara Sāmanta. A detailed study of these translations and the explanations given therein do provide us with substantial insights into the historical development of the concepts, theories, techniques as well as the methodology of the Indian tradition of Astronomy and Mathematics. Many of these insights have also been brought out in various books and monographs that have appeared since 1997 :Hayashi, Kusuba and Yano, 1997; Paramesvaran, 1998; Rao, 2000; Sriram, Ramasubramanian and Srinivas, 2002; Emch, Sridharan and Srinivas, 2005; Raju, 2007; Selin and Narasimha, 2007; Subbarayappa, 2008; Sarma, 2008; Narlikar, 2009; Dash, 2009; Plofker, 2009; Seshadri, 2010; Padmanabhan, 2010; Montelle, 2011; Ramasubramanian, Srinivas and Sriram, 2013; Pingree and. Steele, 2014; Ramasubramanian, 2015; Joseph, 2016; Ramasubramanian, Sule and Vahia, 2016; Selin, 2016; Divakaran, 2018; Kolachana, Mahesh and Ramasubramanian, 2019; Ramasubramanian, Hayashi and Montelle, 2019; Montelle and Plofker, 2019; and also in the various articles published in the two premier Indian Journals, Indian Journal of History of Science (published by the Indian National Science Academy since 1966) and Ganita Bhäratī (published by the Indian Society of History of Mathematics since 1979).

\section{The untapped wealth of manuscripts on Indian Astronomy and Mathematics: The way forward}

While the above discussion shows that significant progress has been achieved by the modern scholarship in Indian astronomy and mathematics during the last seventy years, the fact of the matter is that there are still large gaps in our current knowledge of this great tradition. We shall not here go into the details of the various historical periods and the areas which need to be investigated in depth. Since this discussion is on the untapped wealth of manuscripts in Indian astronomy and mathematics, we have put together a representative list of 188 important source-works which are yet to be edited and published. This list is presented in Appendix B and we may note that, as per the details given in the bibliographies of Pingree 
and Sarma cited above, manuscripts of these works are listed in various catalogues. This list is only indicative of the huge corpus of important source-works which are perhaps easily locatable, but are yet to be edited and studied.

In conclusion, we would like to emphasise we are as yet far from achieving a comprehensive understanding of the fundamental concepts and techniques, theories and methodologies and even the historical development of Indian astronomy and mathematics. This is mainly because:

1. Only 450 (or $5 \%$ ) of the estimated 9,000 source-texts (which are available in the form of manuscripts) have been edited and published so far.

2. Further, even among the 450 or so published works, only about 96 texts have been seriously studied and explicated via translations and explanatory commentaries with a view to bring out their technical (mathematical-astronomical) content.

3. Most of these editions and studies have been brought out during the last seventy years or so; and this is largely due to the voluntary and dedicated efforts of a number of Indian scholars, as there has been little scope or support for such work in our institutions of higher learning.

There is thus an urgent need to reorient our national priorities and give due importance to the preservation, digitization, listing and cataloguing, editing and publishing, and promoting systematic studies of the large corpus of source-works of the great tradition of science and technology in India. Training young scholars for undertaking all these tasks should indeed form an integral part of the courses and research conducted in our institutions of higher learning.

\section{Appendix A}

\section{Source-works of Indian Astronomy and Mathematics which have been translated}

1. Vedāngajyotișa of Lagadha (ca.1300-1100 BCE)

a) English Translation by Jervis (1836)

b) German Translation with Notes by Albrecht Weber (1862) c) English Translation of a portion with Notes by George Thibaut (1877)

d) Marathi Translation by J. B. Modak (1884)

e) English Translation with Notes by Lala Chotelala (1906)

f) English Translation with Notes by R. Shamasastry (1936)

g) Bengali Translation by Sitesh Chandra Bhattacharya (1971)

h) English Translation with Notes by T. S. Kuppanna Sastri and K. V. Sarma (1984)

i) English Translation with Notes by H. M. Jani (1985)

j) English Translation with Notes by P. V. Holay (1989-90)

k) Hindi Translation with Notes by S. A. Kaundinyayana (2005)

1) Kannada Translation with Notes by S. Balachandra Rao (2007)

2. Parāśaratantra of Parāśara (ca.1300-1100 BCE)

a) English Translation of available portions with Notes by R. N. Iyengar (2013)

3. Baudhāyanaśulvasūtra (Prior to ca.800 BCE)

a) English Translation with Notes by George Thibaut (1874-77)

b) Marathi Translation by R. P. Kulkarni (1978)

c) English Translation with Notes by S. N. Sen and A. K. Bag (1983)

d) French Translation with Notes by J. M. Delire (2016)

4. Āpastambaśulvasūtra (Prior to ca.800 BCE)

a) German Translation by A. Burk (1901-2)

b) English Translation by Satya Prakash \& R. S. Sarma (1968)

c) Marathi Translation by R. P. Kulkarni (1978)

d) Japanese Translation with Notes by Yosuke Ikari (1980)

e) English Translation with Notes S. N. Sen and A. K. Bag (1983)

5. Kātyāyanaśulvasūtra

a) English Translation of first two chapters by George Thibaut (1882)

b) English Translation with Notes by S. B. Khadilkar (1974) 
c) Marathi Translation by R. P. Kulkarni (1978)

d) English Translation with Notes S. N. Sen and A. K. Bag (1983)

6. Mānavaśulvasūtra

a) English Translation with Notes by N. K. Majumdar (1922)

b) English Translation with Notes by J. M. Van Gelder (1963)

c) Marathi Translation by R. P. Kulkarni (1978)

d) English Translation with Notes S. N. Sen and A. K. Bag (1983)

7. Atharvanajyotiṣa

a) Hindi Translation by C. L. Sarma and O. N. Dvivedi

b) Hindi Translation with Notes by Abhaya Katyayana (2004)

8. Sūryaprajñapti (in Prākṛta)

a) Hindi Translation by Amolaka Ṛsi (1910)

9. Candraprajñapti (in Prākṛta)

a) Hindi Translation by Amolaka Ṛsi (1909)

10. Bakșāli Manuscript

a) English Translation with Notes by T. Hayashi (1995)

11. Yavanajātaka of Sphūjidhvaja

a) English Translation with Notes by D. Pingree (1978)

b) English Translation of chapter 79 with Notes by B. Mak (2013)

12. Candravākya of Vararuci (ca.4th century CE)

a) English Translation with Notes by K. Kunjunni Raja (1948)

b) English Translation with Notes by T. S. Kuppanna Sastri and K. V. Sarma (1962)

13. Tiloyapaṇnatti (in Prākṛta) of Yativṛșabha (c.5th century CE)

a) Hindi Translation by Vishuddhamati Mataji (1984-86)

14. Āryabhațasiddhānta of Āryabhața (ca.499)

a) English Translation of the Yantrādhyāya with Notes by Kripa Shankar Shukla (1967)
15. Āryabhatīya of Āryabhata (ca.499)

a) Telugu commentary Sudhātarañga by Kodaṇ̣arāma Siddhānti (Composed 1844, Published 1956)

b) Marathi Translation (1860)

c) French Translation of Gaṇitapāda with Notes by L. Rodet (1879)

d) Hindi Translation with Notes by Udaya Narayana Singh (1906)

e) English Translation of Ganitapāda by G. R. Kaye (1908)

f) English Translation with Notes by Baidyanath Rath Sastri (University of Chicago Dissertation 1924, Unpublished)

g) Malayalam Translation of Gītikāpāda by Kolatheri Sankara Menon (1927)

h) English Translation with Notes by P. C. Sengupta (1927)

i) English Translation with Notes by W. E. Clark (1930)

j) Hindi Translation by B. Mishra (1966)

k) German Translation by Kurt Elfering (1975)

1) English Translation with Notes by K. S. Shukla and K. V. Sarma (1976)

m) Hindi Translation by R. N. Rai (1976)

n) Kannada Translation by N. K. Narasimha Murthy (1978)

o) Japanese Translation with Notes by Michio Yano (1980)

p) Malayalam Translation by P. S. Purushottaman Namputiri

q) Kannada Translation with Notes by S. Balachandra Rao (2015)

16. Pañcasiddhāntikā of Varāhamihira (ca.550)

a) English Translation with Notes by George Thibaut and Sudhakara Dvivedi (1889)

b) English Translation with Notes by O. Neugebauer and D. Pingree (1970-71)

c) English Translation with Notes by T. S. Kuppanna Sastri and K. V. Sarma (1985)

17. Bṛhatsaṃhitā of Varāhamihira (ca.550)

a) English Translation with Notes by H. Kern (1870-75)

b) Marathi Translation (1873) 
c) Hindi Translation with Notes by Balasastri Prabhu (1880)

d) Hindi Translation by Durgaprasada (1884)

e) English Translation with Notes by N. Chidambara Iyer (1884-85)

f) Bengali Translation by Rasikamohan Chattopadhyaya (1890)

g) Hindi Translation by Baladev Prasad Mishra (1897)

h) Bengali Translation by Dhirananda Kavyanidhi (1910)

i) English Translation with Notes by V Subrahmanya Sastri and M Ramakrishna Bhat (1947)

j) Malayalam Translation by P. S. Purushottamana Nambutiri (1955)

k) Hindi Translation with Notes by Achyutananda Jha (1959)

1) English Translation with Notes by M. Ramakrishna Bhat (1981-82)

18. Paitāmahasiddhānta of Viṣnudharmottarapurāṇa

a) Translation with Notes by D. Pingree (196768)

19. Mahābhāskarīya of Bhāskara I (ca.620)

a) English Translation with Notes by Kripa Shankar Shukla (1960)

20. Brāhmasphuțasiddhānta of Brahmagupta (ca.628)

a) English Translation of the Ganitāadhyāya and Kutțakādhyāya with Notes by H. T. Colebrooke (1817)

b) Hindi Translation with Notes by R. S. Sharma (1966)

21. Āryabhațīyabhāṣya of Bhāskara I (ca.629)

a) English Translation of the Ganitapāda with Notes by A. Keller (2006)

22. Laghubhāskarīya of Bhāskara I (ca.635)

a) English Translation with Notes by Kripa Shankar Shukla (1963)

23. Khaṇdakhādyaka of Brahmagupta (ca.665)

a) English Translation with Notes by P. C. Sengupta (1934)

b) English Translation with Notes by Bina Chatterjee (1970)
24. Karanaratna of Devācārya (ca.687)

a) English Translation with Notes by Kripa Shankar Shukla (1979)

25. Sūryasiddhānta

a) Bengali Translation (1842)

b) French Translation of two Chapters by J. M. F. Guerin (1847)

c) English Translation by with Notes by Burgess and Whitney (1860)

d) English Translation by Bāpū Deva Śāstri (1861)

e) Bengali Translation by Rasika Mohan Chattopadhyaya (1887)

f) Hindi Translation with Notes by Baladev Prasad Misra (1896)

g) Hindi Translation by Uday Narayan Singh (1903)

h) Hindi Translation by Girija Prasad Dvivedi (1906)

i) Bengali Translation by Swami Vigyanananda and Hariprasad Chattopadhyaya (1909)

j) Hindi Translation with Notes by Mahavir Prasad Srivastava (1940)

k) Malayalam Translation by P. S. Purushottaman Nambutiri (1950)

1) English Translation with Notes by A. K. Chakravarty (2001)

m) English Translation by Bimalananda Saraswati (2007)

26. Gaṇitapañcaviṃśi of Śīdhara (ca.750)

a) English Translation with Notes by D. Pingree (1989)

b) English Translation with Notes by Kripa Shankar Shukla (2017)

27. Pātị̄gaṇita of Śrīdhara (ca.750)

a) English Translation with Notes by Kripa Shankar Shukla (1959)

b) Russian Translation with Notes by A. Volodarskii (1966)

28. Triśatikā of Śrīdhara (ca.750)

a) English Translation of a portion by N. Ramanujacarya and G. R. Kaye (1912-13)

b) Hindi Translation with Notes by Sudyumna Acharya (2004) 
29. Śșyadhīvṛddhida of Lalla (ca.750)

a) English Translation with Notes by Bina Chatterjee (1981)

30. Dhavalā (in Prākṛta) of Vīrasena (ca.800) on Śatkhaṇ̣̂gama of Puṣpadanta and Bhūtabali

a) Hindi Translation by Hiralal Jain (1940-50)

31. Gaṇitasārasañgraha of Mahāvīra (ca.850)

a) English Translation with Notes by M. Rangacharya (1912)

b) Hindi Translation with Notes by L. C. Jain (1963)

c) Kannada Translation with Notes by Padmavatamma (2000)

32. Vāsanābhāṣya on Brāhmasphuțasiddhānta of Brahmagupta by Pṛthūdakasvāmin (ca.860)

a) English Translation of Chapter XXI with Notes by S. Ikeyama (2003)

33. Vațeśvarasiddhānta of Vațeśvara (ca.904)

a) Hindi Translation of first three Chapters with Notes by R. S. Sharma and Mukund Mishra (1962)

b) English Translation with Notes by Kripa Shankar Shukla (1985-6)

34. Laghumānasa of Muñjāla (ca.932)

a) English Translation with Notes by N. K. Majumdar (1944)

b) English Translation with Notes by Kripa Shankar Shukla (1990)

35. Mahāsiddhānta of Āryabhața II (ca.950)

a) English Translation of the Grahaganita part with Notes by S. R. Sarma (1966)

36. Karanatilaka of Vijayanandi (ca.966)

a) English Translation of $\mathrm{Al}$ Biruni's Arabic Translation (Ghurrat al Zijat) with Notes by S. S. H. Rizvi (1963)

b) English Translation of Al Biruni's Arabic Translation (Ghurrat al Zijat) with Notes by Quraishi (1978)

37. Trilokasāra (in Prākṛta) of Nemicandra (ca.975)

a) Hindi Translation by Vishuddhamati (1975)

38. Dhīkoțidakaraṇa of Śrīpati (ca.1039) a) English Translation with Notes by K. S. Shukla (1969)

39. Siddhāntaśekhara of Śrīpati (ca.1039)

a) English Translation of the Vyakta and AvyaktaGaṇita Chapters by K. N. Sinha (1986-89)

b) English Translation of Chapters I-XII by A. Sripada Bhat (2012)

40. Gaṇitatilaka of Śīpati (ca.1039)

a) English Translation by Kripa Nath Sinha (1982)

41. Bhāsvatī of Śatānanda (ca.1099)

a) Hindi Translation with Notes by Matriprasada Pandeya (1917)

42. Pāvalūrigaṇitamu (in Telugu) of Mallaṇa (ca.1100)

a) English Translation of Geometry portion by Benjamin Hyne (1814)

43. Līlāvatī of Bhāskarācārya (ca.1150)

a) English Translation with Notes by J. Taylor (1816)

b) English Translation with Notes by H. T. Colebrooke (1817)

c) Telugu Translation with Notes by Tadakamalla Venkata Krishnarav (1863)

d) Hindi Translation (1876)

e) Marathi Translation with Notes by V. P. Khanapurkar (1897)

f) Hindi Translation with Notes by R. S. Sarma (1905)

g) Telugu Translation by V. Lakshminarayana Sastri (1934)

h) Telugu Translation with Notes by P. Krishnamurthy Sastri (1936)

i) Malayalam Translation by P. K. Koru (1954)

j) Hindi Translation with Notes by Lashan Lal Jha (1961)

k) Kannada Translation with Notes by K. S. Nagarajan (1961)

1) Hindi Translation with Notes by Sita Rama Jha (1970)

m) Marathi Translation with Notes by N. H. Phadke (1971)

n) Hindi Translation by Ramajanma Mishra (1971) 
o) Japanese Translation with Notes by Takao Hayashi (1980)

p) English Translation with Notes by K. S. Patwardhan, S. A. Naimpally and S. L. Singh (2001)

q) French Translation of some Chapters with Notes by Francois Patte (2004)

r) English Translation with Notes by A. B. Padmanabha Rao $(2014,2016)$

44. Bījagaṇita of Bhāskarācārya (ca.1150)

a) English Translation (of the Persian Translation by Ata Alla Rushdi in 1634) by E. Strachey with Notes by S. Davis (1813)

b) English Translation with Notes by H. T. Colebrooke (1817)

c) German Translation of some Chapters with Notes by H. Brockhous (1852)

d) Marathi Translation with Notes by V. P. Khanapurkar (1913)

e) Hindi Translation with Notes by Durgaprasada Dvivedi (1917)

f) Hindi Translation by Visuddhananda Gaur (1943)

g) Hindi Translation with Notes by Achyutananada Jha (1949)

h) Malayalam Translation by P. K. Koru (1960)

i) Hindi Translation by Ramajanma Mishra (1971)

j) English Translation by S. Abhayankar (1980)

k) Hindi Translation with Notes by Devachandra Jha (1983)

1) French Translation with Notes of some Chapters by Francois Patte (2004)

m) English Translation with Notes by V. B. Panicker (2006)

n) English Translation with Notes by T. Hayashi (2009)

45. Siddhāntaśiromaṇi of Bhāskarācārya (ca.1150)

a) Marathi Translation Siddhāntaśiromaṇiprakāśa (1837)

b) Latin Translation of Grahagaṇitādhyāya by E. Roer (1844)

c) English Translation of Golādhyāya by Lancelot Wilkinson and Bāpū Deva Śāstri (1861) d) Bengali Translation of Golādhyāya with notes by Rasika Mohana Chattopadhyaya (1887)

e) Hindi Translation with Notes by Uday Narayan Singh (1905)

f) Hindi Translation with Notes by Girija Prasada Dvivedin (1911, 1926)

g) Marathi Translation with Notes by V. M. Khanapurkar (1911-13)

h) Bengali Translation of Golādhyāya with Notes by Radhavallabha (1921-26)

i) Hindi Translation with Notes by Kedara Datta Joshi (1961-64, 1988)

j) English Translation of Grahagaṇitādhyāya with Notes by Dhulipala Arka Somayaji (1981)

46. Vāsanābhāṣya Autocommentary of Bhāskarācārya on Bījagaṇita (ca.1150)

a) English Translation with Notes by T. Hayashi (2009)

47. Mitākșarā or Vāsanābhāṣya Autocommentary of Bhāskarācārya on Siddhantaśiromaṇi (ca.1150)

a) English Translation of the Vāsanābhāṣya on two chapters of Grahagaṇitādhyāya by Bimalananda Sarasawati (2007)

48. Karaṇakutūhala of Bhāskarācārya (ca.1183)

a) English Translation with Notes by S. Balachandra Rao and S. K. Uma (2008)

49. Śulvadīpikā on Baudhāyanaśulvasūtra by Dvārakānātha Yajvan (ca.12th century)

a) French Translation with Notes by J. M. Delire (2016)

50. Cūḍāmaṇi Ullamudaiyān (in Tamil) of Tirukkotțiyūr Nambi (ca.1234)

a) English Translation with Notes by H. R. Hoisington (1848)

51. Pañcavimiśatikā (ca.13th Century)

a) English Translation with Notes by T. Hayashi (1991)

52. Gaṇitasārakaumudī (in Prākṛta) of Thakkura Pherū (ca.1320)

a) English Translation with Notes by SAKHYA (S. R. Sarma, T. Kusuba, T. Hayashi and M. Yano) (2009) 
53. Ganitakaumudī of Nārāyana Pandita (ca.1356)

a) Japanese Translation of Chapter 14 by T. Hayashi (1986)

b) English Translation of Chapters 13, 14, with Notes by T. Kusuba (Brown University Dissertation 1993, Unpublished)

c) English Translation with Notes by Parmanand Singh (1998-2002)

54. Bījagaṇitāvataṃsa of Nārāyaṇa Paṇdita (ca.1356)

a) English Translation of a portion with Notes by T. Hayashi (2004)

55. Yantrarāja of Mahendrasūri (ca.1370)

a) English Translation of Chapters 1, 2 by S. R. Sarma (2012)

56. Yantrādhikāra of Padmanābha (ca.1400)

a) English Translation with Notes by Y. Ohashi (1997)

57. Dhruvabhramaṇādhikāra of Padmanābha (ca.1400)

a) English Translation of a portion with Notes by S. R. Sarma (2012)

58. Sphuțacandrāpti of Mādhava (ca.1400)

a) English Translation with Notes by K. V. Sarma (1973)

59. Mahājyānayanaprakāra of Mādhava (ca. 1400)

a) Eng. Translation with Notes by D. Gold and D. Pingree (1991)

60. Madhyamānayanaprakāra of Mādhava (ca.1400)

a) English Translation with Notes by U. K. V. Sarma, R. Venkateswara Pai and K. Ramasubramanian (2011)

61. Lagnaprakaraṇa of Mādhava (ca. 1400)

a) English Translation with Notes of Some Chapters by A. Kolachana (IIT Bombay Dissertation 2018, Unpublished)

62. Grahaṇāṣtaka of Parameśvara (ca 1411)

a) English Translation by K. V. Sarma (1958-59)

63. Grahaṇamaṇḍana of Parameśvara (ca.1411)

a) English Translation with Notes by K. V. Sarma (1965)
64. Grahananyāyadīpikā of Parameśvara (ca. 1432-33)

a) English Translation with Notes by K. V. Sarma (1966)

65. Goladīpikā II of Parameśvara (ca. 1432-33)

a) English Translation with Notes by Sho Hirose (University of Paris Dissertation 2017, Unpublished)

66. Goladīpikà I of Parameśvara (ca. 1443-44)

a) English Translation with Notes by K. V. Sarma (1957)

67. Makarandasāriṇ̄ of Makaranda (1478)

a) Hindi Translation with Notes by Gangadhara Tandon (1935)

b) Hindi Translation with Notes by Ramajanma Mishra (1982)

68. Yantracintāmaṇi of Cakradhara (ca.15th Century)

a) Hindi Translation with Notes by Bhagirathi Prasada Sarman (1883)

b) Hindi Translation with Notes by Sundaradeva Sarman (1898)

69. Tantrasañgraha of Nīlakaṇṭha Somayājī (ca.1500)

a) English Translation with Notes by V. S. Narasimhan (1998-99)

b. English Translation with Notes by K. Ramasubramanian and M. S. Sriram (2011)

70. Candracchāyāgaṇita by Nīlakaṇṭha Somayājī (ca. 1500)

a) English Translation by K. V. Sarma (1976)

71. Siddhāntadarpaṇa of Nīlakaṇtha Somayājī (ca.1500)

a) English Translation with Notes by K. V. Sarma (1976)

72. Autocommentary on Siddhāntadarpaṇa by Nīlakaṇṭha Somayājī (ca. 1500)

a) English Translation with Notes by K. Mahesh (IIT Bombay Dissertation 2009, Unpublished)

73. Grahasphutānayane vikșepavāsanā of Nīlakaṇtha Somayājī (ca.1500)

a) English Translation with Notes by K. Ramasubramanian and M. S. Sriram (2011) 
74. Kutțākāraśiromaṇi of Devarāja (ca.15th century)

a) English Translation with Notes by T. Hayashi (2011)

75. Siddhāntasundara of Jñānarāja (ca.1503)

a) English Translation with Notes by Toke Knudsen (2014)

76. Grahalāghava of Gaṇeśa Daivajña (ca.1520)

a) Marathi Translation with Notes by K. S. Godbole and V. S. J. Gadre (1873)

b) Bengali Translation with Notes by Rasika Mohan Chattopadhyaya (1887)

c) Hindi Translation with Notes by Jiyarama Sastri and Ramesvara Bhatta (1899)

d) Telugu Translation with Notes by Mangipudi Virayya Siddhantigar (1917)

e) Hindi Translation with Notes by Sitarama Jha (1941)

f) Hindi Translation with Notes by Yugesvara Jha Sastri (1946)

g) Hindi Translation with Notes by Ramachandra Pandeya (1976)

h) Hindi Translation with Notes by Kedaradatta Joshi (1983)

i) Hindi Translation with Notes by Brahmananda Tripathi (1987)

j) Hindi Translation with Notes by Ramasvarupa Bambai (1987)

k) English Translation with Notes by S. Balachandra Rao and S. K. Uma (2006)

77. Tithicintāmaṇi of Gaṇeśa Daivajña (ca. 1530)

a) Hindi Translation with notes by Matriprasada Pandeya (1938)

b) English Translation with Notes by S. Ikeyama and K. Plofker (2001)

78. Pratodayantra of Gaṇeśa Daivajña (ca. 1530 )

a) English Translation with Notes by Shakti Dhara Sarma (1982)

79. Ekaviṃśatipraśnottara of Citrabhānu (ca. 1530 )

a) English Translation with Notes by T. Hayashi and Y. Kusuba (1998)

80. Ganitayuktibhāṣā (in Malayalam) of Jyeșṭhadeva (ca. 1530) a) Malayalam Commentary on Ganita section by Ramavarma Maru Thampuran and Akhilesvara Aiyar (1948)

b) English Translation With Notes by K. V. Sarma, K. Ramasubramanian, M. D. Srinivas and M. S. Sriram (2008)

81. Sūryaprakāśa on Bījagaṇita of Bhāskarācārya by Sūryadāsa (ca.1538)

a. English Translation of Chapters 1-4 with Notes by Pushpa Kumari Jain (2001)

82. Buddhivilāsin̄i on Līlāvatī of Bhāskarācārya by Gaṇeśa Daivajña (ca.1545)

a) English Translation of selected portions by K. Ramakalyani (Madras University Dissertation 2016, Unpublished)

83. Turīyayantraprakāśa of Bhūdara (1572)

a) English Translation with Notes by SAKHYA (S. R. Sarma, T. Kusuba, T. Hayashi and M. Yano) (2014)

84. Karaṇapaddhati of Putumana Somayājī (ca.1580)

a) Malayalam Translation with Notes by P. K. Koru (1953)

b) English Translation with Notes by R. Venkatesvara Pai, K. Ramasubramanian, M. S. Sriram and M. D. Srinivas (2017)

85. Rāśigolasphuṭaniti of Acyuta Piṣāraṭi (ca.1585)

a) English Translation by K. V. Sarma (1977)

86. Candrārkī of Dinakara (ca.1589)

a) English Translation of portion with Notes by A. Kolachana, C. Montelle, J Dhammaloka, K. Melnad, K. Mahesh, P. Vyas, K. Ramasubramanian, M. S. Sriram and R. Venkatesvara Pai (2018)

87. Bījapallava on Bījagaṇita of Bhāskarācārya by Krșna Daivajña (ca.1600)

a) English Translation of some Portions by M. D. Srinivas (1987)

b) English Translation of some Portions by Sita Sundar Ram (2012)

88. Sūryasiddhāntarahasya of Rāghavānanda Śarman (ca.1591) 
a) Bengali Translation with Notes by Rajanikanta Vidyavinoda (1915)

89. Sarvasiddhāntarāja of Nityānanda (ca.1639)

a) English Translation of the Trigonometry Section with Notes by C. Montelle, K. Ramasubramanian and J. Dhammaloka (2016-18)

b) English Translation of the Golādhyāya with Notes by Anuj Misra (University of Canterbury Dissertation, Unpublished 2016)

90. Pātīsāra of Munīśvara (ca.1650)

a) English Translation of Chapters 1, 2, with Notes by Parmanand Singh and Balesvara Singh (2004-5)

91. Karaṇakesarī of Bhāskara (ca.1681)

a) English Translation with Notes by C. Montelle and K. Plofker (2014)

92. Brahmatulyasāriṇī of Malūkacandra (17th Century)

a) English Translation with Notes by C. Montelle and K. Plofker (2015)

93. Yantrarājaracanā of Savai Jayasiṃha (ca.1725)

a) English Translation with Notes by A. F. Garret and C. Guleri (1924)

94. Yantraprakāra of Savai Jayasiṃha (ca.1725)

a) English Translation with Notes by S. R. Sarma (1989)

95. Sadratnamālā of Śankaravarman (ca.1819)

a) English Translation with Notes by S. Madhavan (2011)

96. Siddhāntadarpaṇa of Candraśekhara Sāmanta (ca.1869)
a) Oriya Translation with Notes by Pandit B. Sas- tri (1976)
b) Hindi Translation by A. K. Upadhyaya (1996)
c) English Translation with Notes by A. K. Upad- hyaya (1996)

\section{Appendix B}

\section{Some important source-works of Indian Astronomy and Mathematics which are yet to be edited and published}

1. Vrddhagargasaṃhitā

2. Gargasaṃhitā

3. Prakațārthadīpikā on Uttarabhāga of Horāśāstra of Parāśara by Goivindasvāmin (ca.800 CE)

4. Vāsanābhāṣya on Brāhmasphuțasiddhānta by Pṛthūdaka (ca.860)

5. Commentary on Laghumānasa by Praśastidhara (ca.958)

6. Commentary on Khaṇdakhādyaka of Brahmagupta by Varuna (ca.1044)

7. Commentary on Khaṇdakhādyaka of Brahmagupta by Someśvara (ca.1050)

8. Sundarī on Laghubhāskarīya of Bhāskara I by Udayadivākara (ca.1073)

9. Commentary on Sūryasiddhānta by Mallikārjuna Sūri (ca.1178)

10. Commentary on Sūryasiddhānta by Caṇdeśvara (ca.1185)

11. Commentary on Laghumānasa by Sūryadevayajvan (ca.1191)

12. Giragasputam (in Tamil) of Tirukkotți Nambi (ca.1234)

13. Sūryasiddhāntapradīpa of Bhāskara Yogin (ca.1235)

14. Karaṇakaṇthīrava of Keśavārka (ca.1250)

15. Bālabodha (in Kannada) on Ganitasārasañgraha of Mahāvīra by Daivajña Vallabha (ca.13th century)

16. Vārșikatantra of Viḍ̣anāāārya (ca.1300)

17. Bhūgolanirnaya with Autocommentary Bhūgolaprakāśa of Vedāntadeśika (ca.1300)

18. Subodha on Bhāsvatī of Śatānanda by Kuvera Śarman (ca.1307)

19. Mahādevasāriṇī of Mahādeva (ca.1316)

20. Grahasiddhi of Mahādeva (ca.1316)

21. Kāmadhenu of Mahādeva (ca.1357)

22. Brahmatulyabhāśya on Karanakutūhala of Bhāskarācārya by Ekanātha (ca.1370)

23. Karaṇakaṇthīrava or Karaṇakesarī of İśvara (ca.1375)

24. Vāsanārṇava on Sūryasiddhānta by Madanapāla (ca.1375)

25. Jyotirājakaraṇa of Jyotirāja (ca.1382) 
26. Bhațapradīpa on Āryabhațīya by Bhūtaviṣnu (ca.14th cent)

27. Gurukațākṣa on Sūryasiddhānta by Bhūtaviṣnu (ca.14th cent)

28. Gaṇakopakāriṇi on Sūryasiddhānta by Colasūrī (ca.14th Century)

29. Gū (ca.1400)

30. Nārmadī on Karaṇakutūhala of Bhāskarācārya by Padmanābha (ca.1400)

31. Yantraratnāvalī with Autocommentary of Padmanābha (ca.1400)

32. Agaṇitagrahacāra of Mādhava (ca.1410)

33. Bhațatulya of Dāmodara (ca.1417)

34. Sūryatulya of Dāmodara (ca.1417)

35. Ganitāmrtasāgarī on Līlāvatī by Gañgādhara (ca.1420)

36. Candracchāyāgaṇita by Parameśvara (ca.1430)

37. Commentary on Vyatīpātāștaka by Parameśvara (ca.1430)

38. Vākyakaraṇa by Parameśvara (ca.1430)

39. Vivaraṇa on Līlāvatī by Parameśvara (ca.1430)

40. Cāndramāna of Gañgādhara (ca.1434)

41. Subodhin̄̄ on Sūryasiddhānta by Rāmakṛ̣ṇa Ārādhya (ca.1472)

42. Commentary on Bhațaprakāśa of Sūryadevyajvan by Yallayya (ca.1480)

43. Kalpavallī on Sūryasiddhānta by Yallayya (ca.1480)

44. Kalpalatā on Laghumānasa by Yallayya (ca.1480)

45. Āndhrațīkā on Grahacandrikāgaṇita of Ākhaṇ̣āla Perājyosyalu by Appayya (ca.1491)

46. Bālabodhin̄̄ on Bhāsvatī of Śatānanda by Balabhadra (ca.1495)

47. Grahakautuka of Keśava (ca.1496)

48. Sudhīrañjanī of Keśava (ca.1496)

49. Commentary on Sūryasiddhānta by Sundararāja (ca.1500)

50. Bījāahyāya of Jñānarāja (ca.1503)

51. Ratnamālā on Bhāsvatī of Satānanda by Acyutabhatța (ca.1505)

52. Tị̂kā on Līlāvatī by Lakṣmīdāsa (ca.1501)

53. Gaṇitatattvacintāmaṇi on Siddhāntaśiromaṇi of Bhāskarācārya by Lakṣmīdāsa (ca.1501)

54. Uparāgadarpaṇa of Tippasūri (ca.1507)

55. Jyotișavākya of Gopendra Tipparāja (ca.1520)

56. Tantraratna of Gopendra Tipparāja (ca.1520)
57. Pātasārin̄ī of Ganeśa (ca.1525)

58. Cābukayantra of Ganeśa (ca.1525)

59. Sudhīrañjanayantra of Gaṇeśa (ca.1525)

60. Jyotihsāarasañgraha of Gaurīnātha Śarman (ca.1528)

61. Uparāgakriyākrama of Nārayaṇa (ca.1525)

62. Commentary on Siddhāntasundara of Jñānarāja by Cintāmaṇi (ca.1530)

63. Grahaganitakalpataru with Autocommentary by Gopīrāja Paṇụita (ca.1540)

64. Vilāsavatī on Yantrarāja of Mahendra Sūri by Gopīrāja (ca.1540)

65. Commentary on Līlāvatī by Sūryadāsa (ca.1540)

66. Commentary on Bījagaṇita by Sūryadāsa (ca.1540)

67. Grahakaumudī of Nrisimha (ca.1548)

68. Khețamuktāvalī of Nrrsimha (ca.1548)

69. Ayanacalanādiganita (in Malayalam) of Śankkara of Mahișamañgalam (ca.1540)

70. Candraganitakrama (in Malayalam) of Śankara of Mahișamañgalam (ca.1540)

71. Pañcabodhagaṇitasàra (in Malayalam) of Śankkara of Mahișamañgalam (ca.1540)

72. Pancbodhakriyākrama (in Malayalam) of Śankara of Mahișamañgalam (ca.1540)

73. Kriyākalāpa by Śankkara Vāriyar (ca.1550)

74. Karaṇasāra with Autocommentary by Śạ̣kara Vāriyar (ca.1550)

75. Laghuvivrti on Pañcabodha by Śankara Vāriyar (ca.1550)

76. Candracchāyāgaṇita of Putumana Somayājī (ca.1570)

77. Apamādinirṇaya of Putumana Somayājī (ca.1570)

78. Candracchāyāgaṇitadaśaka of Putumana Somayājī (ca.1570)

79. Grahaṇagaṇita of Putumana Somayājī (ca.1570)

80. Grahaṇāsțaka of Putumana Somayājī (ca.1570)

81. Nyāyaratna of Putumana Somayājī (ca.1570)

82. Pañcabodha of Putumana Somayājī (ca.1570)

83. Pañcabodhāṣtaka of Putumana Somayājī (ca.1570)

84. Uparāgagaṇita of Putumana Somayājī (ca.1570)

85. Veṇvārohāṣtaka of Putumana Somayājī (ca.1570)

86. Vivaraṇa on Sūryasiddhānta by Bhūdara (ca.1572)

87. Turīyayantraprakāśa by Bhūdara (ca.1572)

88. Tithisārin̄ī by Dinakara (ca.1578)

89. Khetasiddhi by Dinakara (ca.1578)

90. Commentary on Grahalāghava by Dinakara (ca.1578) 
91. Saurabhāṣya on Sūryasiddhānta by Nṛsiṃha Daivajña (ca.1586)

92. Tīk $\bar{a}$ on Tithicintāmaṇi by Nṛsiṃha Daivajña (ca.1586)

93. Manoramā on Grahalāghava by Gañgādhara (ca.1586)

94. Parvadvayasādhana of Mallāri (ca.1588)

95. Makarandapañcānigopapatti of Dhuṇụhīrāja (ca.1590)

96. Rāmavinoda of Rāma (ca.1590)

97. Uparāgakriyākrama of Acyuta Pișārați (ca.1593)

98. Commentary on Āryabhațīya by Raghunātharāja (ca.1597)

99. Laghukaraṇa of Bhāvasadāśiva Bhaț̣a (ca.1598)

100. Grahaganitabhāskara by Tamma Yajvan (ca.1599)

101. Kāmadogdhrī on Sūryasiddhānta by Tamma Yajvan (ca.1599)

102. Commentary on Karaṇakutūhala of Bhāskarācārya by Viśvanātha (ca.1600)

103. Udāharaṇa on Sūryasiddhānta by Viśvanātha (ca.1600)

104. Mitāìkagaṇita by Viśvanātha (ca.1600)

105. Gaṇakaprākāśa by Ekanātha (ca.1600)

106. Tithikalpadruma of Kalyāṇa (ca.1605)

107. Viṣnukaraṇa of Viṣnu (ca.1608)

108. D Drkkaraṇa of Jyeșțhadeva (1608)

109. Pañcāngaśiromaṇi of Tripurāri (ca.1627)

110. Vivaraṇa on Grahatantra of Ahobalanātha by Venkața Yajvan (ca.1627)

111. Siddhāntabindu of Nityānanda (ca.1628)

112. Sarvasiddhāntarāja of Nityānanda (ca.1628)

113. Grahasārin̄ī of Gañgādhara (ca.1630)

114. Commentary on Bījaganita of Bhāskarācārya by Bhāskara (ca.1632)

115. Udāhrti on Grahalāghava of Gaṇeśa by Nārāyaṇa (ca.1635)

116. Jagadbhūṣaṇ̄ of Haridatta (1638)

117. Commentary on Līlāvatī of Bhāskarācārya by Vīreśvara (ca.1638)

118. Commentary on Jyotpatti of Bhāskarācārya by Vīreśvara (ca.1638)

119. Grahavidyādhara of Vidyādhara (ca.1638)

120. Pañcāṅgacvidyādharī of Vidyādhara (ca.1638)

121. Nișștâarthadūtī on Līlāvatī of Bhāskarācārya by Munīśvara (ca.1640)

122. Ekanāthamukhabhañjana by Muniśvara (ca.1640)
123. Mitabhāṣiṇi on Līlāvatī of Bhāskarācārya by Ran்ganātha (ca.1640)

124. Siddhāntacū dāmaṇi of Rañganātha (ca.1640)

125. Siddhāntasāra with Nevārītīkā by Viṣnusimha (ca.1641)

126. Khecaradīpikā of Kalyāṇa (ca.1649)

127. Karaṇaśārdula of Kalyāṇa (ca.1649)

128. Khetaplava of Vīrasiṃha (ca.1650)

129. Āryasiddhāntatulyakaraṇa of Vīrasiṃha (ca.1650)

130. Anūpamahodadhi of Vīrasimha (ca.1650)

131. Grahaprakāśa of Devadatta (ca.1662)

132. Grahaprabodhasārin̄ī of Yādava (ca.1663)

133. Tithidarpaṇa of Murāri (ca.1665)

134. Laghutithidarpaṇa of Murāri (ca.1665)

135. Bhadradīpagaṇita (in Malayalam) by Ițakramañceri Nampūtirī (ca.1665)

136. Commentary on Bhāsvatī of Śatānanda by Gañgādhara (ca.1674)

137. Ganitasāroddhāra of Ānandamuni (ca.1674)

138. Jyotpattisāra of Vidyānātha Sūri (ca.1675)

139. Vijayarāghavīya of Veñkateśa (ca.1675)

140. Commentary on Bhāsvatī of Śatānanda by Kuvera Miśra (ca.1685)

141. Gaṇitāmrtalaharī on Līlāvatī of Bhāskarācārya by Rāmakṛṣna (ca.1687)

142. Bījaprabodha on Bījagaṇita of Bhāskarācārya by Rāmakṛṣna (ca.1687)

143. Commentary on Gaṇitādhyāya of Siddhāntaśiromaṇi of Bhāskarācārya by Rāmakṛṣna (ca.1687)

144. Daivajñamanollāsa (in Telugu) on Laghumānasa of Muñjāla by Ayyālu Bālaya Somayājin (ca.1695)

145. Manorañjana on Līlāvatī of Bhāskarācārya by Rāmakṛșna Deva (ca.17th Century)

146. Grahasiddhi of Trivikrama (ca.1713)

147. Bhramasāriṇ̄ of Trivikrama (ca.1713)

148. Tithisārin̄ī of Trivikrama (ca.1713)

149. Kiraṇāvali on Suryasiddhānta by Dādābhaț̣a (ca.1719)

150. Turīyayantrotpatti of Dādābhatța (ca.1719)

151. Gaṇitārṇava of Nāmanārya (ca.1720)

152. Sūryasiddhāntavyākhyā of Jagannātha (ca.1720)

153. Yantrasāra of Jagannātha (ca.1720)

154. Gaṇitarāja of Kevalarāma Pañcānana (ca.1728)

155. Tithisāriṇī of Kevalarāma Pañcānana (ca.1728)

156. Drkpakṣasāriṇī of Kevalarāma Pañcānana (ca.1728)

157. Rekhāpradīpa of Kevalarāma Pañcānana (ca.1728) 
158. Jayavinodasāriṇ̄ of Sawai Jayasiṃha (ca.1730)

159. Pañcāingādhikāra of Sawai Jayasiṃha (ca.1730)

160. Inakularājatejonidhi by Tulajārāja (ca.1730)

161. Vākyāmṛta by Tulajārāja (ca.1730)

162. Dhruvabhramaṇa of Lakṣmīpati (ca.1740)

163. Sāmrātyantra of Lakșmīpati (ca.1740)

164. Grahadarpaṇa of Bālānanda (ca.1740)

165. Bhāsvatyudāharaṇa of Kamalanārāyaṇa (ca.1740)

166. Khetatantra of Nandisūri (ca.1747)

167. Jyotiṣaśāstrasangraha by Ā⿳̣̂avañceri Tamparākkāl (ca.1750)

168. San்grahasādhanakriyā (Sanskrit and Malayalam) by Āḷavañceri Tamparākkāl (ca.1750)

169. Karaṇadarpaṇa of Bhāradvājadvija (ca.1750)

170. Grahañādarśa of Budhasiṃha Śarman (ca.1764)

171. Karaṇavaiṣnava of Śankkara (ca.1766)

172. Grahaṇapaddhati of Nandarāma Miśra (ca.1770)

173. Goladarpaṇa of Nandarāma Miśra (ca.1770)

174. Yantrasāra of Nandarāma Miśra (ca.1770)

175. Grahāgama of Govindasūnu (ca.1773)

176. Golānanda of Cintāmaṇi Dīkṣita (ca.1775)

177. Pattraprakāśa of Viśrāma Śukla (ca.1777)

178. Yantrarājakalpa of Mathurānātha Śukla (ca.1782)

179. Jyotihnsiddhāntasāra of Mathurānātha Śukla (ca.1782)

180. Kaṇakkuśāstram (in Malayalam) by Koccukṛṣnan Āsān (Kṛṣṇadāsa) (ca.1790)

181. Pañcabodha (in Malayalam) by Koccukṛṣnan Āsān (Kṛṣnadāsa) (ca.1790)

182. Commentary on Äryabhațīya (in Malayalam) by Koccukṛṣṇan Āsān (Kṛṣṇadāsa) (ca.1790)

183. Āryabhațīyavyākhyā (in Sanskrit and Malayalam) by Ghatigopa (ca.1800)

184. Ganitāmrta of Abbayakavi (ca.1807)

185. Mihiraprakāśa of Kulānanda (ca.1810)

186. Grahaprakāśa of Kāśīnātha (ca.1813)

187. Siddhantarāja of Bālakṛṣna Vedavṛkṣa (ca.1820)

188. Karaṇabhūṣaṇa of Cunnīrāma (ca.1837)

\section{Bibliography}

[1] Aufrecht, T. Catalogus Catalogorum: An Alphabetical Register of Sanskrit Works and Authors, 3 Volumes, Leipzig, 1891, 1896 and 1903.

[2] Bag, A. K. Mathematics in Ancient and Medieval In- dia, Chowkhambha, Varanasi, 1979.

[3] Biswas, S. C. and Prajapati, M. K. Bibliographic Survey of Indian Manuscript Catalogues, Eastern Book Linkers, Delhi, 1998.

[4] Bose, D. M., Sen, S. N. and Subbarayappa, B. V. A Concise History of Science in India, Indian National Science Academy, New Delhi 1971.

[5] Burgess, E. Translation of the Sūryasiddhānta with Notes and an Appendix, American Oriental Society, New Haven, 1860.

[6] Burgess, James. Notes on Hindu astronomy and the History of our Knowledge of it, Journal of the Royal Society, 25 (1893): 717-761.

[7] Colebrooke, H. T. Algebra with Arithmetic and Mensuration from the Sanscrit of Brahmagupta and Bhascara, John Murray, London, 1817.

[8] Dash, S (Ed.), Facets of Indian Astronomy: A Collection of Articles of Professor K. V. Sarma, Rashtriya Sanskrit University, Tirupati, 2009.

[9] Datta, B. B. The Science of the Ślba A Study in Early Hindu Geometry, University of Calcutta, Calcutta, 1932.

[10] Datta, B. B. and Singh, A. N. History of Hindu Mathematics: A Source Book, Parts I, II, Motilal Banarsi Das, Lahore, 1935, 1938.

[11] Dikshit, S. B. Bhāratīya Jyotih Sāstrācā Prācīna Āṇi Arvācīna Itihāsa (in Marathi), Aryabhushan Press, Pune, 1896, Eng. Tr. by R. V. Vaidya: Bharatiya Jyotish Sastra, 2 Volumes, Controller of Publications, Delhi, 1969, 1981.

[12] Divakaran, P. P. The Mathematics of India, Concepts: Methods Connections, Hindustan Book Agency, 2018. Reprinted, Springer New York, 2018.

[13] Dvivedin, Sudhakara. Gaṇakatarangiṇ̄, Varanasi, 1892.

[14] Emch, G. G., Sridharan, R. and Srinivas, M. D. (Eds.), Contributions to History of Indian Mathematics, Hindustan Book Agency, New Delhi, 2005. 
[15] Hayashi, T., Kusuba, T. and Yano, M. Studies in Indian Mathematics: Series, $\pi$ and Trigonometry (in Japanese), Tokyo, 1997.

[16] Iyengar, C. N. Srinivasa. History of Indian Mathematics, The World Press, Calcutta, 1967.

[17] Janert, K. L. An Annotated Bibliography of the Catalogues of Indian Manuscripts Part I, Franz Steiner Verlag, Wiesbaden, 1961.

[18] Joseph, G. G. Indian Mathematics: Engaging the World from Ancient to Modern Times, World Scientific, London, 2016.

[19] Kolachana, A., Mahesh, K. and Ramasubramanian, K. (Eds.), Studies in Indian Mathematics and Astronomy: Selected Articles of Kripa Shankar Shukla, Hindustan Book Agency, New Delhi, 2019.

[20] Montelle, C. Chasing Shadows Mathematics Astronomy and the Early History of Eclipse reckoning, Johns Hopkins University Press, Baltimore, 2011.

[21] Montelle, C. and Plofker, K. Sanskrit Astronomical Tables, Springer, New York, 2019.

[22] Narlikar, J. V. (Ed.), Science in India, Centre for Studies in Civilisations, New Delhi, 2009.

[23] Padmanabhan, T. (Ed.), Astronomy in India A Historical perspective, Indian National Science Academy, New Delhi, 2010.

[24] Paramesvaran, S. The Golden age of Indian Mathematics, Swadeshi Science Movement, Kochi, 1998.

[25] Pingree, D. Sanskrit Astronomical tables in the United States, American Philosophical Society, Philadelphia, 1968.

[26] Pingree, D. Sanskrit Astronomical Tables in England, KSRI, Madras, 1973.

[27] Pingree, D. 'Mathematical Astronomy in India', in C. G. Gillespie (Ed.), Dictionary of Scientific Biography, Vol. XV, New York, 1978, pp. 433-533.

[28] Pingree, D. Jyotihśāastra Astral and Mathematical Literature, Otto Harrassowitz, Wiesbaden, 1981.
[29] Pingree, D. Census of the Exact Sciences in Sanskrit, Series A, volumes I-V, American Philosophical Society, Philadelphia, 1970, 1971, 1976, 1981 and 1994.

[30] Pingree, I. and Steele, J. M. (Eds.), Pathways into the Study of Ancient Science: Selected Essays by David Pingree, The American Philosophical Society Press, Philadelphia, 2014.

[31] Plofker, K. Mathematics in India, Princeton University Press, Princeton, 2009.

[32] Pollock, S. The Language of Gods in the World of Men, University of California Press, Berkeley, 2006.

[33] Raju, C. K. Cultural Foundations of Mathematics: The Nature of Mathematical Proof and the Transmission of the Calculus from India to Europe in the $16^{\text {th }}$ c.CE, Pearson Education, Delhi, 2007.

[34] Rao, S. Balachandra. Indian Astronomy: An Introduction, Universities Press, Hyderabad, 2000.

[35] Ramasubramanian, K., Srinivas, M. D. and Sriram, M. S. NPTEL Course on Development of Mathematics in India from Vedic Period to Modern Times, IIT Madras, 2013 (http://nptel.ac.in/courses/ $111101080 /$ )

[36] Ramasubramanian, K. (Ed.), Gaṇitānanda: Selected Works of Radha Charan Gupta on History of Mathematics, ISHM, New Delhi, 2015.

[37] Ramasubramanian, K., Sule A. and Vahia, M. (Eds.), History of Indian Astronomy: A Handbook, IIT Mumbai, 2016.

[38] Ramasubramanian, K., Hayashi, T. and Montelle, C. (Eds.), Bhāskara-prabhā, Hindustan Book Agency, New Delhi, 2019.

[39] Sarma, K. V. A History of the Kerala School of Hindu Astronomy, Vishveshvaranand Institute, Hoshiarpur, 1972.

[40] Sarma, K. V. Science Texts in Sanskrit in the Manuscript Repositories of Kerala and Tamil Nadu, Rashtriya Sanskrit Sansthan, New Delhi, 2002.

[41] Sarma, S. R. The Archaic and the Exotic: Studies in Indian Astronomical Instruments, Manohar, New Delhi, 2008. 
[42] Saraswati Amma, T. A. Geometry in Ancient and Medieval India, Motilal Banarsidass, Delhi, 1979.

[43] Selin, H. and Narasimha R. (Eds.), Encyclopaedia of Classical Indian Sciences, Universities Press, Hyderabad, 2007.

[44] Selin, H. (Ed.), Encyclopaedia of the History of Science Technology and Medicine in the Non Western Cultures, 3rd Ed., Springer, New York, 2016.

[45] Sellamutthu, K. C. et. al (Eds.), A Union Catalogue of Tamil Manuscripts, Vol. V, Tamil University, Thanjavur, 1991.

[46] Sen, S. N, Bag, A. K. and Sarma, S. R. A Bibliography of Sanskrit Works on Astronomy and Mathematics, National Institute of Sciences India, Delhi, 1966.

[47] Sen, S. N. and Shukla, K. S. (Eds.), History of Indian Astronomy, Indian National Science Academy, New Delhi 1985.

[48] Sengupta, P. C. The Khaṇdakhādyaka, University of Calcutta, Calcutta, 1934.

[49] Sengupta, P. C. Introduction, in P. Gangooly (Ed.), Translation of Sūryasiddhānta by Ebenezer Burgess, University of Calcutta, Calcutta 1935.

[50] Seshadri, C. S. (Ed.), Studies in the History of Indian Mathematics, Hindustan Book Agency, New Delhi, 2010.

[51] Sriram, M. S., Ramasubramanian, K. and Srinivas, M. D. (Eds.), 500 Years of Tantrasangraha: A Landmark in the History of Astronomy, IIAS, Shimla, 2002.

[52] Subbarayappa, B. V. The Tradition of Astronomy in India Jyotihśāstra: Centre for Studies in Civilisations, New Delhi, 2008.

[53] Thibaut, G. Astronomie, Astrologie und Mathematik, Karl J. Trubner, Strassburg, 1899.

[54] Wujastyk, D. 'Indian Manuscripts', in J. B. Quenzer (Ed.), Manuscript Cultures Mapping the Field, De Gruyter, Berlin, 2014. 